\title{
Appeal Against Acquittal By The Prosecutor: Critical Comments on The Indonesian Constitutional Court Decision
}

\author{
Aristo Pangaribuan \\ University of Washington Law School \\ aristo01@uw.edu
}

\begin{abstract}
In 2013, the Indonesian Constitutional Court ended the debate concerning the constitutional validity of the right to appeal against acquittal by the prosecutor. Such a question has a long history not only in the Indonesian judicial system. In their decision, the court concluded that the government should have the power to appeal against acquittal to the Supreme Court because of its supervisory function over the lower courts. However, the decision was not unanimous, and there was one dissenting opinion from justice Harjono, who is in favor of protecting the rights of the acquitted defendant. This article is trying to examine the decision and underlined the issue of two competing values, namely finality, and accuracy that was debated in the decision, even though the court did not explicitly mention it. In the end, this article finds that the court gives more importance to the accuracy of the conviction and less to their finality.
\end{abstract}

Keywords: Acquittal; Appeal; Constitutional Court; Indonesia; Kasasi.

\section{A. Introduction}

Acquittal means a victory for the defense. However, there is still a possibility that the losing parties (in this case, the prosecutor) view such victory as unjust. On the other hand, the defendant might feel 
that giving another avenue to the state to appeal his acquittal to the Supreme Court is totally unfair because it would create another unpredictability of the outcome. Apart from that, the Indonesian Supreme Court always made its decision by merely reviewing the trial records from the lower courts. Because of this situation, in 2013 a civil servant named Idrus lodged a petition to the Constitutional Court ("court") challenging the constitutionality of appeal against acquittal in Indonesia. Idrus was acquitted of corruption charge by the lower courts. And because of his acquittal, the prosecutor seeks an appellate reversal of an unfavored result. Examining Idrus's petition, the court is facing a task to define the principle of legal certainty under the 1945 constitution.

Such situation gives rises to two competing interest in defining the principle of legal certainty: the need to have a finality and the need to have accuracy. ${ }^{1}$ The former assumes that by giving more importance to the finality, it means protecting the defendant by not allowing the state to appeal. Meanwhile, the latter considers that there should be some way for the government to right the wrong. The Indonesian Constitutional Court with 8-1 decision says accuracy outweigh finality.

It is worth to examine on how the Court concluded that the government's action to appeal against acquittal is in line with the principle of legal certainty and the rule of law set forth by the Constitution. This article will examine this debate by discussing the weight of the defendant's constitutional right to have a legal certainty after the acquittal and the government interest to make repeated attempts to convict an individual in order to reach an accurate decision. In short,

1 See for instance the discussion about finality versus accuracy in U.S criminal justice system in Forrest G Alogna, "Double Jeopardy, Acquittal Appeals, and the Law-Fact Distinction,” CORNELL LAW REVIEW 86 (n.d.): 35. However, please keep in mind that U.S follows adversarial system which view the criminal trial as an equal battle between the defendant and the state. Therefore, asymmetrical appeal deviates from adversarial archetype. Meanwhile, Indonesian follows inquisitorial system, which view the criminal trial as a process of inquiry by the state. Asymmetrical appeal is not an unknown concept in this setting. 
this article is questioning the constitutionality of acquittal appeals. The constitution alone is unable to answer the question of whether the government may appeal a defendant's acquittal to uphold the legal certainty principle because the terms of legal certainty are not self-defining.

\section{B. Overview of Appeal Against Acquittal in Indonesia}

The question about whether the government through prosecutors can appeal on acquittal is widely debated in Indonesia. The 1981 Indonesian Criminal Procedural Law ("KUHAP”) explicitly says that the prosecutor does not have any right to appeal against acquittal. Originally, the stipulation is seen as an instrument to protect the defendant from double jeopardy or ne bis in idem, thus giving the defendant the right to have legal certainty. What I mean by legal certainty in this paper is predictability in the law-applying activities. Even though the KUHAP was enacted during the dictatorship regime of President Soeharto, it is heavily influenced by the international human rights convention which acknowledges the defendant is in a vulnerable position when facing the government in criminal cases. ${ }^{2}$ Theoretically speaking, the prohibition against appealing against the acquittal based on the argument that the defendant must not bear the risk of any legal error conducted by the government in criminal cases. The government, through its legal apparatus, has an enormous power to seek material truth through investigation that allows the police and the prosecutor to "legally" violate the human rights of its people. Therefore, the criminal defendant is entitled to have constitutional protection prohibiting the government from appealing against acquittal. ${ }^{3}$

However, in 1983, the situation changed. The Supreme Court, for the first time, granted an appeal by the government against an

2 It can be seen in the elucidation of KUHAP in paragraph 3, in which it is a translation of article 14 of the International Convenant on Civil and Political rights.

3 Anne Bowen Poulin, GOVERNMENT APPEALS IN CRIMINAL CASES: THE MYTH OF ASYMMETRY, 77 Univ. CINCINNA TI LAW Rev. 63. p.206 
acquittal of Natalegawa, the executive of the state-owned bank, in the case of corruption. ${ }^{4}$ At that time, the Supreme Court justices argued that they faced contra legem situation because as the highest court in Indonesia, the Supreme Court must ensure that the law is correctly applied. With that in mind, the judge interpreted that there are two conditions of acquittal: ${ }^{5}$ the real acquittal and tainted acquittal (bebas murni dan bebas tidak murni). The judges in their verdict argued that the new interpretation towards acquittal is needed because the existing law is no longer able to perform as an instrument to reach justice. ${ }^{6}$ In the case of Natalegawa, the Supreme Court judges specifically argued that the acquittal decision from the first court, Central Jakarta District Court, is based on the wrong interpretation of the law. The Supreme Court judges argued the first instance court judges imposes a limited interpretation of "against the law" element.

During the same year, in December, the Minister of Justice enacted regulation abolishing the restriction for the prosecutor to appeal against acquittal. It is not entirely clear who was the initiator of the abolishment - the Supreme Court decision dated December 29th, 1983 and the Minister of Justice regulation dated December 10th. It is because, during the authoritarian era, the Supreme Court administration is under the domain of the Ministry of Justice. Therefore, it is hard to say that there was no discussion between the Minister of Justice and the Supreme Court concerning the appeal against acquittal on Natalegawa case. Both the decision and the minister's regulation sanctioning the same issue with the same argument: under exceptional circumstances, the government is allowed to file an appeal against tainted acquittal decision.

The decision from the Supreme Court judgment triggered a substantial debate in Indonesia. The proponent of the abolishment

4 See Indonesia Supreme Court Decision No. 275/K/Pid/1983 concerning Natalegawa case.

5 The definition of two type of acquittals can be found in 1983 Minister of Justice Regulation: Kep Menkeh TAMBAHAN PEDOMAN PELAKSANAAN KITAB UNDANG-UNDANG HUKUM ACARA PIDANA 1983)

6 Pini Alvionita, UPAYA KASASI TERHADAP PUTUSAN BEBAS DALAM PERKARA PIDANA 12. P.44. 
hailed the decision as a landmark decision. They argued that the restriction of appeal would undermine the power of the Supreme Court as the highest court to oversee the lower courts. There is a risk of legal error in the lower court, and the restriction will eliminate the function of the Supreme Court to revise the lower court decision. ${ }^{7}$ On the contrary, the opponent of the abolishment argued that the abolishment based on the Supreme Court and the Minister's regulation is merely illegal due to the hierarchy of authority of the law. According to the hierarchy of law, both the Supreme Court decision and the minister's regulation could not override KUHAP.

Moreover, the principle of legal certainty is at risk because the defendant will have to face the unpredictability of the outcome of a criminal trial. Regardless of the debate, the Supreme Court always allows an appeal through cassation against acquittal. The prosecutor also must appeal against acquittal, regardless of the situation. ${ }^{8}$ However, it is worth to question the government's motivation in abolishing the restriction sanctioned by KUHAP. Under the dictatorship regime of Soeharto, rights are routinely violated, but there is no realistic avenue for redress. ${ }^{9}$ That is why the decision to abolish the restriction with inferior law was suspected of being politically driven.

In March 2013, the Constitutional Court ended the debate. The Constitutional Court examined the constitutional question posed by Idrus, a retired civil servant from the island of Sumatera. The criminal district court found Idrus not guilty of corruption charged by the prosecutor in 2008. Subsequently, after the acquittal, the prosecutor lodged a kasasi to the Supreme Court. Idrus argued that the appeal from the Supreme Court would violate his right to have legal certainty for himself. Because of the appeal by the prosecutor, the outcome

7 See for instance, the editorial of Hukumonline discussing about the history of appeal against acquittal in Indonesia. https: / / www.hukumonline.com/ berita/baca/lt54a1d82fe8974/kisah-icontra-legem-i-pasal-244-kuhap/

8 The obligation is mandated by State Attorney Regulation in SURAT EDARAN KEJAKSAAN AGUNG REPUBLIK INDONESIA NOMOR B-533/E/EPL/10/1993 TAHUN 1993

9 Robert R Strang, "More Adversarial, but not Completely Adversarial": Reformasi of the Indonesian Criminal 
of the trial becoming uncertain. In his petition, Idrus cited article 1 para (3), article 27 para (1) and article $28 \mathrm{D}$ para 1 of the Indonesian constitution. The said articles are as follow: ${ }^{10}$

Article 1 para (3):

"The State of Indonesia shall be a state based on the rule of law."

Article 27 para (1):

"All citizens shall be equal before the law and the government and shall be required to respect the law and the government, with no exceptions.

Article 28D para (1):

"Article 28D (1) every person shall have the right to recognition, guarantees, protection, and certainty before a just law, and of equal treatment before the law."

The petition requested the Constitutional Court to review the constitutionality of article 244 KUHAP concerning restriction on the appeal against acquittal. The defendant argued that his constitutional rights are being violated because the prosecutor appeals to his acquittal. In his petition, the defendant explained that there are at least five reasons why he submitted a constitutional review to the Constitutional court. ${ }^{11}$ First, his constitutional right to legal certainty is violated because the prosecutor appealed the acquittal to the Supreme Court even though the KUHAP sanctioned otherwise. The petitioner argued that the principle of legal certainty is an essential feature of the state who declared itself as a state based on the rule of law. Second, his constitutional rights are violated because of the implementation of the article 244 KUHAP.

Even though the article 244 stated that an appeal against acquittal decision is not allowed, another interpretation by the government and the Supreme Court deviates from KUHAP. As a consequence, there is uncertainty about the outcome of his case. Third, with the appeal, the petitioner will suffer from the specific and actual damage.

10 The translation is not an official translation, it is provided by the author.

11 This five reasons requirement is based on the Constitutional Court decision 006/PUU-III/2005 juncto Putusan Nomor 11/PUUV/2007. This requirement is needed to convince the court to do a constitutional review. 
The petitioner's status as an innocent man can be overturned easily by the Supreme Court even though there is legal protection from the KUHAP. Forth, there is a correlation between the damage suffered by the petitioner and the law. The petitioner argued that his right is violated because of the multi-definition ${ }^{12}$ on article 244 . If there is a single definition on article 244 , his trial outcome will be predictable, and the principle of legal certainty is upheld. Fifth, if his request is granted, then there would be no more constitutional violation by the government. The petitioner requested the Constitutional Court to define and interpret the constitutionality of article 244 KUHAP. He requested the Constitutional Court to test the constitutionality of an appeal against acquittal. The petitioner argued that a formal opinion from the Constitutional Court is needed to resolve the debate so that there will be no more violation of the principle of legal certainty.

Before this constitutional review, the Constitutional Court already dismissed four constitutional reviews against acquittal appeal based on formality. In their five previous decisions, the Constitutional Court decided that the petitioner was not capable of lodging constitutional review because the government does not directly violate their rights. Unlike those five decisions, in Idrus's situation, the court concluded that the petitioner satisfied subjective requirement because his rights are directly violated by the appeal of the government. When considering the constitutionality of appeal against acquittal, the court explicitly acknowledge the KUHAP does not provide any room for the prosecutor to appeal an acquittal. The court stated that: ${ }^{13}$

The court realized that practically speaking, an appeal against acquittal can be appealed to the Supreme Court through kasasi. Whereas, legally speaking, according to the written law, appeal against acquittal to the Supreme Court is not allowed. As a consequence, the principle of legal certainty as mandated by the Constitution is currently in question. In light of this situation, the Court needs to decide the constitutionality of

12 I am of the opinion that the wording on the article 244 KUHAP does not provide any room for another interpretation.

13 The original document is written in Indonesia, the translation is provided by the author without modifying the meaning of the opinion 
article 244 KUHAP, especially the phrase "except for acquittal.

However, the court concluded that article 244 KUHAP is constitutionally invalid. It was no surprise when the court started its argument by citing the Supreme Court's role of supervision. The court explained that the restriction to appeal against acquittal decision to the Supreme Court would undermine its function as a court of cassation to supervise the lower court's decision. ${ }^{14}$ Moreover, the court cited Article 24 paragraph 1 of the Constitution, which stated that the judicial authority is an independent authority to achieve justice based on the rule of law. Based on that principle, the court explained that the appeal against acquittal decision from lower courts does not automatically mean that the defendant is guilty and must be punished. Still, there is a possibility that the acquittal itself confirmed by the Supreme Court. With that in mind, the Court concluded that it is reasonable to declare the government's action to appeal against acquittal decision is constitutional. The court ended its argument by saying, by allowing the Supreme Court to supervise the lower court's decision, law and order are established.

Responding to that argument, justice Harjono is the only justice that dissented such opinion. He follows the rationale that the defendant must not bear the risk of any legal error done by the state legal apparatus. He argued that the restriction to appeal against acquittal in article 244 KUHAP must be seen as an instrument to protect the defendant's rights. ${ }^{15}$ He explained: ${ }^{16}$

During the criminal trial, the rights of the defendant are being violated because of his status as a defendant. With that status, it becomes legal for the government to violate the defendant's human rights, such as his freedom. If, after a series of a trial, the judge concluded that the defendant is not guilty, then such decision, on behalf of the principle of legal certainty, must be final. If the government failed to protect the defendant's right, then it must be questioned what the purpose of having the trial is?

It is interesting to see that the debate about the appeal by the

14 See page 27 para 3.13 .1 of the decision

15 See page 33 of the decision

16 Translation is provided by the author. 
government against the acquittal also happened in the Constitutional Court. Eight out of nine justices agreed that the government should be allowed to appeal against acquittal to the Supreme Court. Only one justice opined that the acquittal decision must be final and binding as mandated by the original text written in article 244 KUHAP. It is clear since the beginning; the KUHAP prohibit acquittal appeals. The government is the one that violates the prohibition, the Supreme Court accepted it, and the uncertainty begins. Almost two decades later, the constitutional court decided to end the uncertainty by favoring the government.

\section{Finality versus Accuracy}

Even though the decision did not mention the competing values between finality and accuracy, the real issue of appeal against acquittal by the government is on how to find a balance between finality and accuracy. Such a situation is not exclusive only in Indonesia. For instance, in the common law system, the acquitted defendant was protected against the double jeopardy of further prosecution in respect of the same offense. However, this protection is not absolute. In the US, prosecutors may appeal against acquittal if the appeal solely based on legal determinations which would require no further fact-finding. ${ }^{17}$ In the last few years, the reform on the double jeopardy principle is also happening in the United Kingdom. Acquittals for a specific offense, if tainted by the offense hindering the administration of justice or when there is new and compelling evidence of guilt, it may be retried. ${ }^{18}$ In this situation, there is a tension between the need to have absolute finality in favor of the defendant and the government interest to have an accurate decision. Even though the court's decision did not specifically mention the debate between finality and accuracy, it is evident in the decision when the eight justices cited the need to have a thorough supervision of lower courts from the

17 Anne Bowen Poulin, Double Jeopardy and Judicial Accountability: When Is an Acquittal Not an Acquittal?, Ariz. STATE LAW J. p. 41.

18 David Hamer, The Expectation of Incorrect Acquittals and the "New and Compelling Evidence"' Exception to Double Jeopardy, Crim. Law Rev. 18 (2009). 
Supreme Court. In other words, the constitutional analysis weighed the prosecutor's interest in having an accurate decision against the right of the acquitted defendant to have a finality of the decision as written in KUHAP.

The eight justices argued in consideration of the decision in paragraph 3.13.1 as follows: ${ }^{19}$

As the highest court of the four judiciaries, it is imperative that the Supreme Court holds the authority to adjudicate at the level of appeal against the decision of the four judiciaries which are under it.

In their argument, the eight justices are trying to convince us that the supreme court, as the highest court in Indonesia is responsible for supervising the decision from the lower courts. Moreover, in paragraph 3.13.4, the eight justices then explained the purpose of the supervision: ${ }^{20}$

In the enforcement of law and justice, it also contains the meaning that the truth must be told and the wrong must be declared wrong.

The eight justices were speaking about the need to have an accurate decision because they defined legal certainty equals accuracy. They explained it by saying, "[t]he truth must be declared, and the wrong must be declared wrong." In contrast, justice Harjono argued against accuracy argument. Justice Harjono cited the need to have law and fact distinction as a threshold for the appeal against acquittal. He argued as follows: ${ }^{21}$

Therefore it is clear that KUHAP distinguishes the two [acquittal and dismissal] Article 191 Paragraph (1) related to evidence in court which cannot prove whereas the defendant has committed the action being accused, whilst the Paragraph (2) in the court proves the defendant has committed an action, but the action is not a criminal act. It [types of acquittals] must be separated between the question of fact and the question law.

Justice Harjono argued that an appeal is not permissible against

19 Translation is provided by the author.

20 Translation is provided by the author

21 Translation is provided by the author 
acquittal decision. The KUHAP already sanctioned that an appeal is only permitted when the defendant is dismissed on purely legal determinations. Justice Harjono then explained why he is in support of the finality argument:

To those [criminal defendants] who have undergone criminal proceedings, whose human rights are being violated because of his status as criminal defendant, in which the state has the power to detain him, yet the prosecutor still could not proves that they are the one who committed the accused act, thus as a consequences, their rights shall be respected and protected for the sake of legal certainty. If their rights are not protected then the proceedings which they have undergone are questionable, where the proceedings were by the law; therefore the decision has to be respected.

He blatantly said that the finality claim of acquittal decision is absolute because the human rights of the criminal defendant are being violated since the start of criminal proceedings. Moreover, the procedure itself is done according to the lawful procedure, and there is no reason not to respect the acquittal decision.

Examining the debate between finality and accuracy of criminal proceedings serves as a framework on how the court tried to interpret the question of defining the principle of legal certainty. The subsequent question, therefore, is whether the absolute finality of the acquittal written in KUHAP has any bearing on the authority of the government to appeal. To answer the foregoing question, we must first identify the constitutional value that underlies the acquittal, and then determine the relevance of the value to a government appeal. The finality argument takes two separate forms - one based on the expectations a defendant has, and the other based on the expectations he is entitled to have. ${ }^{22}$

Even though the KUHAP has stated clearly that the government has no right to appeal against acquittal under article 244, the Constitutional Court decided that the article 244 constitutionally invalid because it undermines the legal certainty principle. The problem is,

22 Peter Westen, THE THREE FACES OF DOUBLE JEOPARDY: REFLECTIONS ON GOVERNMENT APPEALS OF CRIMINAL SENTENCES, 78 Mich. Law Rev. 66. p.1007. 
legal certainty has two faces: From the objective point of view legal certainty is treated as predictability in the law-making or law-applying activities, from the subjective one it is viewed as the subjects' feeling concerning the stability of law and legal security. ${ }^{23}$ Unfortunately, the court did not present a detailed discussion on the legal certainty principle in their judgment. The court only concluded that they must interpret the constitutionality of article 244 for the sake of legal certainty because there is an ongoing confusion between what is written and what is practiced. In the end, the court interpreted the legal certainty principle in favor of the government. Deviating from KUHAP, the court sanctioned that the government must be given the right to appeal against acquittal for the sake of the accuracy. Greater accuracy decreases acquittals of guilty defendants.

The decision was no surprise because in Indonesia, the main purpose of having criminal justice administration is to have an accurate decision. History has showed us that there was a time when the prosecutor is allowed to use a case review (peninjauan kembali), a mechanism that is specifically designed only for the defendant to request a review against a final and binding decision such as in Pollycarpus case in 2006. Under Indonesian law, only the criminal defendant could call for a case review, if the defendant found new evidence in the case. However, in common law tradition, appeal against acquittal is under strict scrutiny because the double jeopardy clause protects criminal defendants from most government appeals of acquittals, even where the acquittal based upon an error done by the prosecutor. ${ }^{24}$

The KUHAP is following the rationale of finality argument: that once a person has been acquitted of an offense, the government must respect that judgment. Even if it disagrees with the result, it cannot bring a second prosecution against the same person for the same of-

23 Anthony D’Amato, Legal Uncertainty, 71 Calif. Law Rev. 1 (1983).

24 The Supreme Court of the United States in Green v. United States explained that one of the underlying concerns of the rule against double jeopardy "is that the state with all its resources and power should not be allowed to make repeated attempts to convict an individual for an alleged offense, thereby subjecting him to embarrassment, expense and ordeal." 
fense. ${ }^{25}$ A person acquitted of a crime, along with his family needs to live peacefully after the acquittal. Without prohibiting the government from appealing against acquittal, a person found not guilty of a crime could never be sure that he was effectively acquitted, no matter how many times a trier of fact found him not guilty, for the government could repeatedly try him until it attained a conviction. It is no surprise when the KUHAP is taking the liberal point of view because partly, the enactment of KUHAP was heavily influenced by The International Covenant on Civil and Political Rights (ICCPR), a product of liberal democracy. Lack of finality in criminal proceedings will violate the individual right to plan his or her life.

The article 244 KUHAP originally is intended, in part to minimize the expense and distress to an individual accused of a crime by confining it to a single trial. Once he is acquitted, there is no need for him to undergo the trauma of the trial proceedings. Moreover, the purpose of prohibiting a new trial of an individual following his acquittal also prevents the government from attempting to retry a person after having failed to convince the judge in the first trial. Therefore, there is an expectation from the defendant that he is entitled to have the finality of his acquittal. Apart from that, allowing the government to appeal against acquittal will increase the risk of erroneously convicting an innocent person. It is because multiple prosecutions would permit the government to use the first trial as a "rehearsal" allowing the prosecutor to perfect its trial strategies.

The discussion presented by the court is very limited. Their main argument is based on the supervisory role of the Supreme Court as the court of cassation. There is no discussion about balancing and weighing the defendant's interest and the state's interest to have accurate adjudication. On the one hand, prolonging the defendant's exposure to the uncertain outcome is equal to compelling him to live in a continuing state of insecurity, which violates his constitutional right to have certainty. On the other hand, the government also has

25 The discussion about how to respect acquittal can be found in David S Rudstein, Retrying the Acquitted in England Part II: The Exception to the Rule Against Double Jeopardy for "Tainted Acquittals" 77. p243 
an interest in having accurate adjudication. The constitutional debate should be centered at the accuracy and finality debate. ${ }^{26}$

I agree that the law should give a room for the government to right their wrong. Especially in Indonesia, there is a huge possibility that an acquittal resulted from judicial corruption. If there is no recourse, the public interest to prosecute a criminal case is gone. There is an apparent reason for the reluctance to treat finality as an absolute value because the claim of finality is threatening the legal order because they operate to confer blanket immunity on defendants without regard to their factual guilt or innocence. The higher the weight that is accorded the finality value, the higher the frequency that factually guilty defendants will go free. It is not surprising, therefore when the court decided, that the finality value itself is not absolute, and that there is always a need to balance the society's valid concern for ensuring that the guilty are punished. ${ }^{27}$

However, the court should have drawn a clear line on the question when an acquittal is not an acquittal. In order to answer the question, the court needs to find a balance between two competing values. The court should define the what it means to have a supervisory function of the Supreme Court. The court should translate its supervisory function based on law and fact distinction of appeal. Meanwhile, the Supreme Court must consistently sanction that appeal against acquittal can only be done if there are any legal errors in trial law which would require no further fact finding. Unfortunately, in Indonesia, the law and fact distinction are blurry, and the judges argue that the law inquiry is a gateway to re-investigate the fact.

\section{Conclusions}

The Court has ruled in favor of permitting appeal against acquittal by the prosecutor. In their argument, the eight justices stress the need to supervise lower courts from judicial error. The one and the only dissenting opinion from justice Harjono has favored the defendant based

26 Forrest G Alogna, Double Jeopardy, Acquittal Appeals, and the Law-Fact Distinction, 86 CORNELL LAW Rev.35

27 Westen, supra note 19. 
on the argument that the defendant must be released from the risk of legal error conducted by the state. Harjono argued that, it has to be seen like that because the state has ample resources, while criminal defendants are powerless when facing enormous power of the prosecutor, especially in the inquisitorial justice system. The decision showed that the need to have accurate decision does outweigh the need to have finality.

The failure to draw a line between pure acquittals and tainted acquittals could create a room for abuse by the state. Although the court decision ended the terminology of pure acquittal and tainted acquittal, the interaction between law-fact distinctions has never been critically examined by the court. In the civil law tradition, the court of cassation is primarily not to rule on the merits, but to state whether the law has been correctly applied based on the facts already definitively assessed in the decisions referred to it. The fundamental purpose of the Court of Cassation, as stated in the Supreme Court law is to assure the uniformity of interpretation and application of the law. Based on that situation, the law-fact distinction inquiry must consistently serve as a threshold to appeal against acquittal.

In Indonesia, theoretically speaking, prosecutorial appeal through a court of cassation is only permitted on a question of law alone. However, the practice is the question of law is frequently used as an excuse to reinterpret the facts.

\section{Bibliography}

Alogna, F. G. (n.d.-b). Double Jeopardy, Acquittal Appeals, and the Law-Fact Distinction. CORNELL LAW REVIEW, 86, 35.

Alvionita, P. (n.d.). UPAYA KASASI TERHADAP PUTUSAN BEBAS DALAM PERKARA PIDANA. 12. Ariawan, I. G. K. (2010). PENEROBOSAN TERHADAP BATAS-BATAS KEBEBASAN KEKUASAAN KEHAKIMAN. (4), 10.

Cassese, A. (n.d.). The Belgian Court of Cassation v. The International Court of Justice: The Sharon and others Case. 17.

D’Amato, A. (1983). Legal Uncertainty. California Law Review, 71(1), 
1. https:// doi.org/10.2307/3480139 Hairi, P. J. (2011). Antara Prinsip Peradilan Sederhana, Cepat dan Berbiaya Ringan dan Gagasan Pembatasan Perkara Kasasi. 2(1), 28.

Hamer, D. (2009a). The Expectation of Incorrect Acquittals. Criminal Law Review, 63-78.

Hamer, D. (2009b). The Expectation of Incorrect Acquittals and the "'New and Compelling Evidence"' Exception to Double Jeopardy. Criminal Law Review, 18.

Jaffe, L. L. (1955). Judicial Review: Question of Law. Harvard Law Review, 69(2), 239. https: / / doi.org/10.2307/1337867

. (1956). Judicial Review: Question of Fact. Harvard Law Review, 69(6), 1020. https: / / doi.org/10.2307/1337537

Kasasi Terhadap Putusan Bebas. , 114/PUU-X/2012 (Constitutional Court of Indonesia March 26, 2013). Kep Menkeh TAMBAHAN PEDOMAN PELAKSANAAN KITAB UNDANG-UNDANG HUKUM ACARA PIDANA. , Pub. L. No. M.14-PW.07.03 TAHUN 1983 (1983).

Kordela, M. (2008). THE PRINCIPLE OF LEGAL CERTAINTY AS A FUNDAMENTAL ELEMENT OF THE FORMAL CONCEPT OF THE RULE OF LAW. Revue Du Notariat, 110(2), 587. https:// doi.org/10.7202/1045553ar

Lamsu, A. (n.d.). ABSTRAK Mahkamah Agung merupakan puncak dari upaya (hukum) dalam mencari keadilan melalui proses peradilan baik sebagai pengadilan tingkat kasasi maupun pengadilan untuk pemeriksaan peninjauan. (4), 9.

Marshall, P. D. (n.d.). A Comparative Analysis of the Right To Appeal. INTERNATIONAL LAW, 22, 46.

Miller, J. (n.d.). Appeals by the State in Criminal Cases. 28.

Poulin, A. B. (1995). Double Jeopardy and Judicial Accountability: When Is an Acquittal Not an Acquittal. Arizona State Law Journal, (3), 953-992.

(n.d.). GOVERNMENT APPEALS IN CRIMINAL CASES: THE MYTH OF ASYMMETRY. UNIVERSITY OF CINCINNA TI LAW REVIEW, 77, 63.

Rudstein, D. S. (n.d.). Retrying the Acquitted in England Part II: The Ex- 
ception to the Rule Against Double Jeopardy for "Tainted Acquittals." 77.

Simamora, J. (n.d.). The Legal Certainty of Prosecutor's Cassation against Acquittal. 7(1), 17.

Steinglass, J. (n.d.-a). THE JUSTICE SYSTEM IN JEOPARDY: THE PROHIBITION ON GOVERNMENT APPEALS OF ACQUITTALS. INDIANA LAW REVIEW, 31, 31. (n.d.-b). THE PROHIBITION ON GOVERNMENT. INDIANA LAW REVIEW, 33.

Stitht, K. (n.d.). The Risk of Legal Error in Criminal Cases: Some Consequences of the Asymmetry in the Right to Appeal. The University of Chicago Law Review, 63.

Suhariyanto, B. (n.d.). LEGAL FLEXIBILITY IN A PETITION OF CASE REVIEW BY PUBLIC PROSECUTOR. Jurnal Komisi Yudisial, 8(2), 17.

The Notions of Certainty, Finality and Predictability. (2012, April 4). Retrieved July 17, 2019, from Opinio Juris website: http: / / opiniojuris.org/2012/04/04/the-notions-of-certainty-finality-andpredictability/

Tumpa, H. A. (2015). Penerapan Konsep Rechtsvinding dan Rechtsschepping oleh Hakim dalam Memutus Suatu Perkara. Hasanuddin Law Review, 1(2), 126. https:// doi.org/10.20956/halrev. $\underline{\mathrm{v} 1 \mathrm{n} 2.90}$

Westen, P. (n.d.). THE THREE FACES OF DOUBLE JEOPARDY: REFLECTIONS ON GOVERNMENT APPEALS OF CRIMINAL SENTENCES. Michigan Law Review, 78, 66. 